\title{
Investment Costs of the Building EnVelope Reconstructions
}

\author{
Miloslav Výskala ${ }^{1}$ \\ ${ }^{1}$ Department of Structural Economics and Management, Faculty of Civil Engineering, \\ Brno University of Technology, Brno, Czech Republic \\ vyskala.m@fce.vutbr.cz
}

\begin{abstract}
The article is aimed at the design of the measurements improving the thermal-technical properties of the building envelope from the point of view of the economic evaluation. The starting point for the evaluation of economic aspects is the quantification of the partial and total costs according to the individual constructions of the building envelope in relation to the earlier requirements. The result is the determination of the minimal thickness of the thermal insulation i.e. the determination of the corresponding properties of the building envelope. Described procedure represents the first step for the consecutive modelling of the potential investment options while comply with the optimal level according to Directive 2010/31/ES (EPBD II).
\end{abstract}

Keywords: thermal-technical properties, building envelope, thermal insulation, economic efficiency

\section{INTRODUCTION}

One of the requirements regarding future constructions and first of all the reconstructions of the buildings already existing is the need for the sufficient thermal-technical protection especially in connection with the Directive of the European Parliament and the European Committee for Energy Performance of Buildings from 19 May 2010. This directive among others establishes the common frame for the methods of the energy performance calculations. It defines the minimal requirements for the energy performance of buildings while maintaining the optimal cost level [1] [later dealt with in detail in 2].

In case of maintenance work or reconstructions, the interventions into the construction of the building envelope are common and it is necessary to evaluate the already existing technical but especially thermal-technical characteristics of it in the project preparation. Investments into the improvement of the thermal-technical characteristics of the buildings arise from the unsatisfactory technical condition of the above mentioned constructions for example the unified prefabricated concrete constructions [3] as well as from the need for the operating cost savings especially those for heating.

An important aspect in the investment decisions is the economic evaluation of the partial measures. Thus the planned investment has to take into account this. 
The aim of this article is to introduce the comprehensive procedure which enables the compilation of the assumed total investment costs for the constructions which improve the thermal-technical characteristics of the buildings being the input parameter for the monitoring of the economic efficiency of the investment. The prerequisite for the determination of the total investment costs is the knowledge of the local environment and historical thermo-technical requirements put on the individual constructions. If the approximate age of the construction is known it is easily possible to determine the basic parameters. What is more it enables to suppose that the building when finished met these requirements. The result is thus such solution which results from the existing condition and at the same time it fulfils the current thermo-technical requirements at least at minimal level.

Currently there are available widespread and fully accessible types of software (for example: "PROTECH" or "ENERGIE" frequently used in the Czech Republic) which enable the calculation of the energy performance of buildings and their sorting into some of the energy categories. The technology for the improvement of the thermo-technical characteristics while using a wide range of insulating materials is also known. However, there is no link-up to the model calculation of economic sustainability and efficiency which would provide the investor complex information about investment possibilities. This paper introduces the procedure on the basis of which it is possible to estimate generally the total investment costs.

\subsection{Metodology}

The first step in solving the problem is to determine the legal and technical requirements placed on the design of the building envelope (Chapter 2). This is followed by the development of these requirements in the Czech Republic. For each object can be determined by the difference between the current reality and requirement (Chapter $3)$. This difference corresponds to the added thickness of the thermal insulation. The next section in the costs of the necessary sub-structures (Chapter 4). In conclusion, the total costs are fixed.

Total and fractional costs corresponding with the costs for the assembly entry according to the catalogue of the target prices of the pricing system ÚRS Praha, a. s.

\section{THERMO-TECHNICAL REQUIREMENTS PUT ON THE CONSTRUCTION OF THE BUILDING ENVELOPE}

Constructions under the requirements for the thermo-technical characteristics of buildings are concentrated near the building envelope on the boundary between the heated and unheated areas of the building. As the shell of the building are considered all the constructions on the system boundary of the whole building [4] which are subject to the influence of the outer environment. Constructions of the building shell can be divided in:

- roofs (pitched, flat),

- ceiling constructions separating heated and unheated areas,

- external walls (light, heavy, adjacent partly or fully to the heated area, not adjacent to the heated area),

- floors (adjacent to the soil),

- window, door and other openings (openings of outlets in the roof, walls) [5]. 
Particular technical requirements for designing of the constructions which ensure the fulfilment of the basic requirement for the thermal protection are specified by the national technical standards (in the Czech Republic - the technical standard CSN 730540 Thermal protection of buildings) in the way that it ensures especially:

- thermal comfort of the users,

- required thermo-technical characteristics of the construction,

- condition of the inner environment for the technological activities and breeding animals,

- low energy demandingness while building functioning [6].

Standards are obligatory and valid for new buildings. For the construction changes of the building envelope, maintenance work, changes in the use of the buildings and other changes to already finished constructions it is necessary to provide a technical and economic evaluation of the individual constructions affected.

It is inevitable to apply the requirements to all construction changes, maintenance work and changes in the use of the buildings in the way that while the investment costs are kept the same, the total energy performance of the building is decreased and the impact on the environments is minimized. This means that in the long-time perspective the investment costs have to be compensated by the saving in the heating costs.

One of the determining thermo-technical characteristics for the individual part of the building shell is the thermal transmittance $\mathrm{U}$-value $\left[\mathrm{W} / \mathrm{m}^{2} \mathrm{~K}\right]$.

\section{THERMO-TECHNICAL CHARACTERISTICS OF THE BUILDING ENVELOPE}

One of the criteria for the determination of the investment costs for the improvement of the thermo-technical characteristics of the building envelope for the already finished buildings is the determining of the character of the materials and constructions elements used.

While determining the actual characteristics it is generally possible to come out of the historic requirements of the above mentioned technical standard even if the materials used in the shell are not known. If it is possible to estimate the age of the building it is also possible in relation to the national and geographical specifics approximately determine the constructiontechnological processes and materials used and thus it is possible to determine the already valid thermal transmittance $\mathrm{U}$-value $\left[\mathrm{W} / \mathrm{m}^{2} \mathrm{~K}\right]$. Historical development of the thermal transmittance U-value according to the Czech technical standards for the individual constructions can be seen from Table 1.

From the table the development of the requirement since the half of the 20 century up to now can be seen. Requirement of the thermal transmittance U-value is historically determined for the materials existing in that period. For most of the buildings the dual revaluation of the requirement is typical. 


\begin{tabular}{|c|c|c|c|c|c|c|c|c|c|c|c|c|c|}
\hline & & 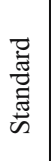 & $\begin{array}{l}0 \\
\widetilde{\delta} \\
0 \\
0 \\
Z \\
\text { Zn }\end{array}$ & \multicolumn{4}{|c|}{ CSN 730540} & \multicolumn{6}{|c|}{ CSN 73 0540-2 } \\
\hline & & 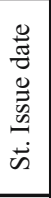 & 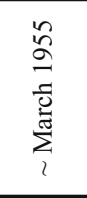 & 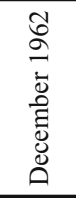 & 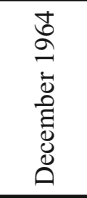 & 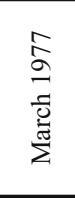 & $\begin{array}{l}\stackrel{\Omega}{\sigma} \\
\frac{\vec{\Xi}}{2}\end{array}$ & $\begin{array}{l}\text { 吕 } \\
\frac{\vec{\sigma}}{2}\end{array}$ & 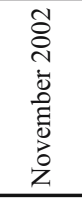 & 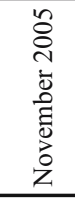 & 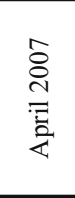 & 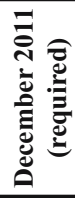 & 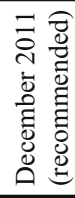 \\
\hline \multirow{2}{*}{$\begin{array}{l}\text { Flat roof, roof up } \\
\text { to } 45^{\circ}\end{array}$} & light & & \multirow[b]{2}{*}{1.163} & 0.545 & 0.545 & \multirow[b]{2}{*}{0.508} & \multirow[b]{2}{*}{0.316} & 0.276 & 0.240 & \multirow[b]{2}{*}{0.240} & \multirow[b]{2}{*}{0.240} & \multirow[b]{2}{*}{0.240} & \multirow[b]{2}{*}{0.160} \\
\hline & heavy & & & 0.900 & 0.900 & & & 0.316 & 0.300 & & & & \\
\hline \multirow{2}{*}{ Outer wall } & light & & \multirow[b]{2}{*}{1.396} & \multirow[b]{2}{*}{1.467} & \multirow[b]{2}{*}{1.467} & \multirow[b]{2}{*}{0.894} & \multirow[b]{2}{*}{0.461} & 0.405 & 0.300 & 0.300 & 0.300 & \multirow[b]{2}{*}{0.300} & 0.200 \\
\hline & heavy & & & & & & & 0.461 & 0.380 & 0.380 & 0.380 & & 0.250 \\
\hline \multirow{2}{*}{$\begin{array}{l}\text { Ceiling under the } \\
\text { unheated attic }\end{array}$} & light & & \multirow[b]{2}{*}{1.163} & \multirow[b]{2}{*}{0.905} & \multirow[b]{2}{*}{0.905} & \multirow[b]{2}{*}{0.901} & \multirow[b]{2}{*}{0.339} & \multirow[b]{2}{*}{0.308} & 0.240 & \multirow[b]{2}{*}{0.300} & \multirow[b]{2}{*}{0.300} & \multirow[b]{2}{*}{0.300} & \multirow[b]{2}{*}{0.200} \\
\hline & heavy & & & & & & & & 0.300 & & & & \\
\hline \multicolumn{3}{|l|}{$\begin{array}{l}\text { Ceiling over the } \\
\text { unheated cellar }\end{array}$} & 1.163 & 0.930 & 0.930 & 1.017 & 0.750 & 0.723 & 0.600 & 0.600 & 0.600 & 0.600 & 0.400 \\
\hline \multicolumn{3}{|l|}{$\begin{array}{l}\text { Floor adjacent to } \\
\text { the soil }\end{array}$} & - & 1.108 & 1.108 & 1.091 & 0.600 & 0.462 & 0.380 & 0.380 & 0.380 & 0.450 & 0.300 \\
\hline \multirow{2}{*}{ Outer windows } & normal & & \multirow[b]{2}{*}{4.652} & \multirow[b]{2}{*}{-} & \multirow[b]{2}{*}{-} & \multirow[b]{2}{*}{3.700} & & & & 1.700 & 1.700 & 1.500 & 1.200 \\
\hline & pitched & & & & & & 2.700 & 2.900 & 1.800 & 1.500 & 1.500 & 1.400 & 1.100 \\
\hline Outer door & $\begin{array}{c}\text { withou } \\
\text { vest. }\end{array}$ & & & & & & 4.300 & 3.200 & 1.800 & 1.700 & 1.700 & & \\
\hline & with ves & & - & - & - & 4.760 & 5.500 & 5.500 & 3.500 & 3.500 & 3.500 & 1.700 & 1.200 \\
\hline
\end{tabular}

Table 1. Historical development of the thermal transmittance $\mathrm{U}$-value $\left[\mathrm{W} / \mathrm{m}^{2} \mathrm{~K}\right]$ according to the Czech standard CSN (Czech technical standard) [7]

The first one took place in the period of 60 s and 70 s of the 20 century when the increase in the unification in the construction industry appeared and the use of sandwich reinforced concrete panels replaced the classical brick construction of the outer walls. The second turning point can be seen at the beginning of the 90 s when the significant change in the use of the materials for the construction of the building shells in connection with the liberalization of the market and availability of "western" technologies appeared.

\section{COSTS FOR THE IMPROVEMENT OF THE THERMOTECHNICALCHARACTERISTICS OF THE BUILDING ENVELOPE}

The costs for the improvement of the thermo-technical characteristics of the building envelope are mainly determined by the requirement for the complementation of each construction structure with a new thermo-insulating layer or set of layers. The thickness of the thermal insulation directly depends on the required (or better recommended) difference and the already existing thermal transmittance $U$-value $\left[\mathrm{W} / \mathrm{m}^{2} \mathrm{~K}\right]$. The necessary thickness of the thermo insulator in connection with the changes of the outer walls using contact insulating system can be seen from Table 2 . The thickness of the insulator is identical for the individual time periods in which the fierce changes in the requirement did not appear.

According to the defined structuring of the individual layers of the envelope it is possible to choose and design a specific construction improving the thermo-technical characteristics of the 
building for each individual part of it. Concerning costs it is possible to assign each identified solution a corresponding technology and chosen insulation material.

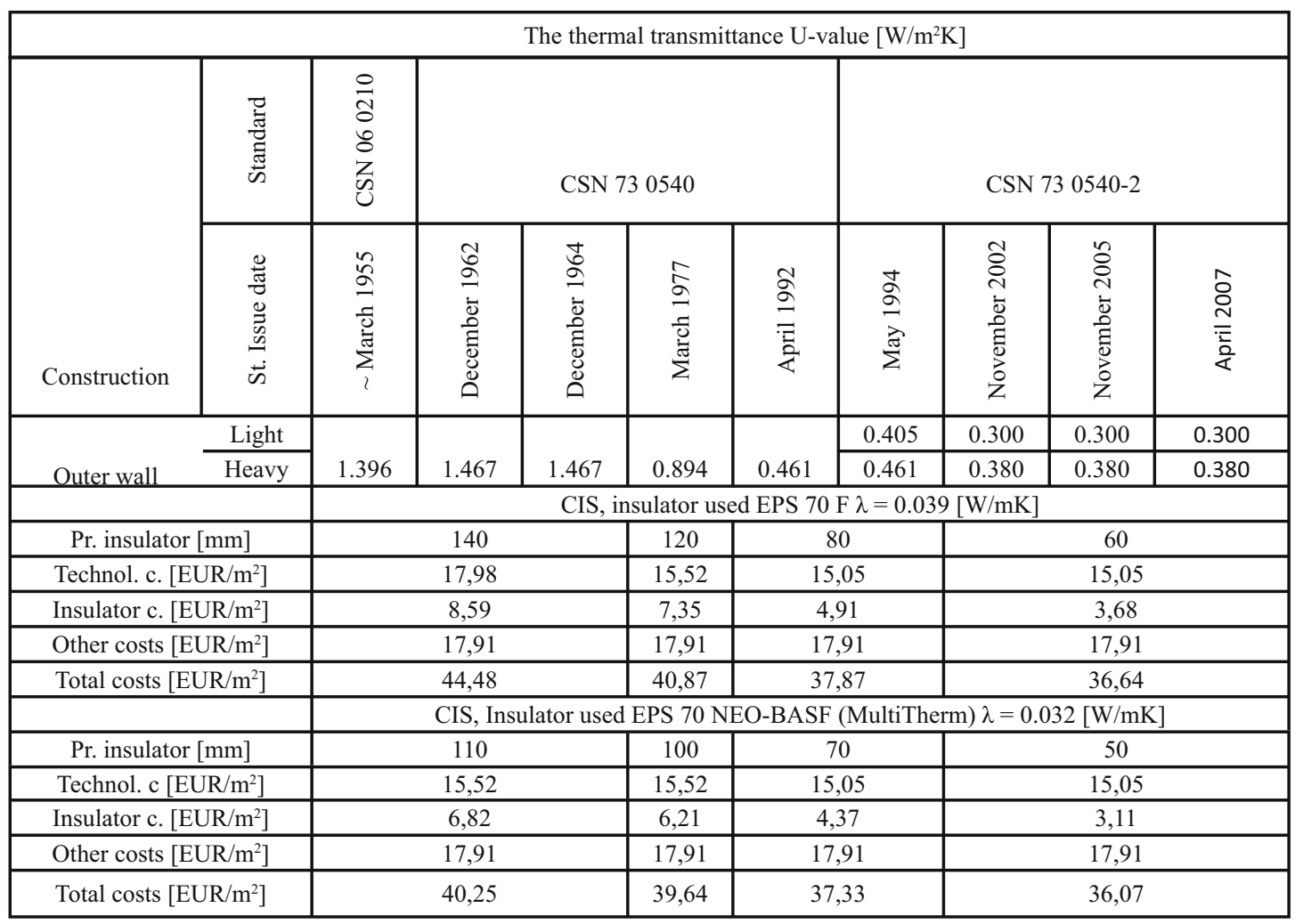

Table 2. Costs for the improvement of the thermo-technical characteristics of the building envelope - CIS [author, with use of 6,7]

Notes:

- ${ }^{1}$ Necessary thickness of the insulator got from the calculation of the thermal transmittance $\mathrm{U}$-value $\mathrm{U} \leq \mathrm{U}_{\mathrm{N}}$ recommended (acc.to CSN 73 0540-2:2011), production scale for individual insulating slabs is respected.

- $\quad{ }^{2}$ Technological costs corresponding with the costs for the assembly entry according to the catalogue of the target prices of the pricing system ÚRS Praha, a. s. č. 622121001 (- 041) Assembly of the insulation of the outer walls by polystyrene slabs thickness up to $40(-200) \mathrm{mm}$. (Price level 2013)

- $\quad{ }^{3}$ Costs for the insulator corresponding with the acquisition costs of the facade polystyrene slabs EPS thickness according to the specification in the table. (Price level 2013)

- ${ }^{4}$ Other costs comprising the silicon-silicate thin plaster th. $2.0 \mathrm{~mm}$, assembly, disassembly and scaffolding hire and costs for delivery and assembly of the system slats converted to $\mathrm{m} 2$. (Price level 2013)

- All the costs listen in Table 2 are in EUR and come from the target prices of the national database for building constructions and materials. 
The total costs are necessary to convert to the unit of measure and divide into:

- costs for assembly (by the chosen technology),

- costs for the insulator,

- other related costs.

The determined division of the total costs best corresponds with the need for the setting apart the costs for the insulator which may change with the thickness of the insulator. The costs for the assembly and other related costs do not change depending on the thickness of the insulator i.e. are the same for several thicknesses of the insulator [in more detail 8].

As an example it is possible to look at the most commonly used contact insulation systems (CIS), where the costs for assembly are understood as the costs necessary for the faultless technological accomplishment of the construction, especially for the sticking and embedding the insulator and construction of the armouring layer using levelling cement and glass fibre fabric. The costs can be for example determined from the comprehensive national pricing systems used in construction industry. The second possibility is represented by the real offer prices of the individual potential contractors.

The costs for material are represented by the acquisition costs of the insulating materials. In case of contact insulating systems it is a group of synthetic materials (on the basis of polystyrene) and mineral (stone wool and glass fibre wool). In each of the potentially suitable materials it is necessary to take into account also the amount of the primary energy needed for the production of the material [9].

Other costs are understood as the other necessary costs arising in the direct relationship to the chosen technology, for example scaffolding construction, surface finishing etc.

The total costs then express the expected costs connected to the realization of one unit of measure of the set construction concerning the building envelope.

In case of outer walls it is possible to use some of the technological processes listed in Table 3.

\begin{tabular}{|c|c|c|c|}
\hline $\begin{array}{l}\text { Part of the construction } \\
\text { of the building shell }\end{array}$ & $\begin{array}{l}\text { Thermo insulation } \\
\text { acc. to technology }\end{array}$ & $\begin{array}{c}\text { Material } \\
\text { of insulation }\end{array}$ & $\begin{array}{l}\text { Example of specification } \\
\text { of thermo insulation }\end{array}$ \\
\hline \multirow{4}{*}{ Walls } & \multirow[t]{2}{*}{ CIS } & Polystyrene & $\begin{array}{c}\text { EPS } 70 \mathrm{~F} \\
\text { EPS } 100 \mathrm{~F} \\
\text { Slabs on basis of PS } \\
\text { XPS }\end{array}$ \\
\hline & & Mineral wool & $\begin{array}{l}\text { Fibres vertically } \\
\text { Fibres horizontally }\end{array}$ \\
\hline & \multirow[t]{2}{*}{ PZS } & Polystyrene & $\begin{array}{c}\text { EPS } 70 \mathrm{~F} \\
\text { EPS } 100 \mathrm{~F} \\
\text { Slabs on basis of PS } \\
\text { XPS }\end{array}$ \\
\hline & & Mineral wool & $\begin{array}{l}\text { Fibres vertically } \\
\text { Fibres horizontally }\end{array}$ \\
\hline
\end{tabular}

Table 3. Technology for improvement of the thermo-technical characteristics of the building envelope [8] 
According to the specific requirements for individual buildings it is necessary to deal with all the available technologies treating the thermo-technical characteristics of the buildings in detail. The investment target in from the economic point of view is the comparison of different options while the crucial criterion is the return of the investment while observing technical and thermo-technical requirements at the same time.

Creation of the total costs proceeds according to the above mentioned procedure depending on the technological process used and specification of the insulator. The total costs for CIS for various technological processes and insulators suitable for them are listed in Table 4.

\begin{tabular}{|c|c|c|c|c|c|c|c|c|c|c|}
\hline \multirow[b]{3}{*}{ Construction } & \multicolumn{10}{|c|}{ The thermal transmittance U-value $[\mathrm{W} / \mathrm{m} 2 \cdot \mathrm{K}]$} \\
\hline & \multirow{2}{*}{ 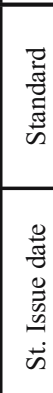 } & \multirow{2}{*}{ 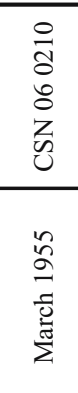 } & \multicolumn{4}{|c|}{ CSN 730540} & \multicolumn{3}{|c|}{ CSN 73 0540-2 } & \multirow[b]{2}{*}{ 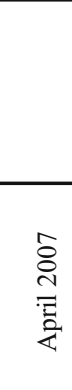 } \\
\hline & & & 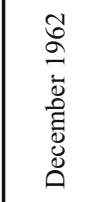 & 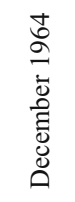 & 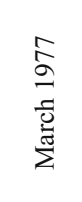 & $\frac{\widetilde{\sigma}}{\bar{\sigma}}$ & $\begin{array}{l}\stackrel{+}{\sigma} \\
\stackrel{\Xi}{\Sigma}\end{array}$ & 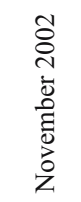 & 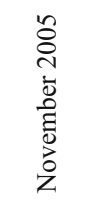 & \\
\hline \multirow{2}{*}{ Outer wall } & ight & \multirow[b]{2}{*}{1.396} & \multirow[b]{2}{*}{1.467} & \multirow[b]{2}{*}{1.467} & \multirow[b]{2}{*}{0.894} & \multirow[b]{2}{*}{0.461} & 0.405 & 0.300 & 0.300 & 0.300 \\
\hline & \multirow[t]{2}{*}{ heavy } & & & & & & 0.461 & 0.380 & 0.380 & 0.380 \\
\hline & & \multicolumn{9}{|c|}{ CIS, insulator used EPS $70 \mathrm{~F}, \lambda=0.039[\mathrm{~W} / \mathrm{mK}]$} \\
\hline \multicolumn{2}{|c|}{ Thick. insulator [mm] } & \multicolumn{3}{|c|}{140} & 120 & \multicolumn{2}{|c|}{80} & \multicolumn{3}{|c|}{60} \\
\hline \multicolumn{2}{|c|}{ Total costs $\left[\mathrm{EUR} / \mathrm{m}^{2}\right]$} & & $40,48^{1}$ & & 40,87 & & 87 & & 36,64 & \\
\hline & & \multicolumn{9}{|c|}{ CIS, insulator used EPS 70 NEO-BASF, $\lambda=0.032[\mathrm{~W} / \mathrm{mK}]$} \\
\hline \multicolumn{2}{|c|}{ Thick. insulator [mm] } & \multicolumn{3}{|c|}{110} & 100 & \multicolumn{2}{|c|}{70} & \multicolumn{3}{|c|}{50} \\
\hline \multicolumn{2}{|c|}{ Total costs $\left[\mathrm{EUR} / \mathrm{m}^{2}\right]$} & & 40,25 & & 39,60 & & & & 36,06 & \\
\hline & & \multicolumn{9}{|c|}{ CIS, insulator used EPS GreyWall, $\lambda=0.032[\mathrm{~W} / \mathrm{mK}]$} \\
\hline \multicolumn{2}{|c|}{ Thick. insulator $[\mathrm{mm}]$} & \multicolumn{3}{|c|}{120} & 100 & \multicolumn{2}{|c|}{80} & \multicolumn{3}{|c|}{60} \\
\hline \multirow{2}{*}{\multicolumn{2}{|c|}{ Total costs $\left[\mathrm{EUR} / \mathrm{m}^{2}\right]$}} & & 42,35 & & 40,87 & & 92 & & 37,44 & \\
\hline & & \multicolumn{9}{|c|}{ CIS, insulator used ISOVER TF, $\lambda=0.036[\mathrm{~W} / \mathrm{mK}]$} \\
\hline \multicolumn{2}{|c|}{ Thick. insulator [mm] } & & 140 & & 120 & & & & 60 & \\
\hline Total costs [EU & & & 61,37 & & 54,73 & & & & 43,14 & \\
\hline & & & $\overline{\mathrm{CIS}}$ & ssulato & sed ISC & $\overline{\text { ER NF }}$ & $333, \lambda=$ & $.041[\mathrm{~W}$ & $\overline{\mathrm{mK}]}$ & \\
\hline Thick. insulato & & & 160 & & 140 & & & & 80 & \\
\hline Total costs [EL & & & 61,74 & & 58,81 & & 73 & & 48,33 & \\
\hline
\end{tabular}

Table 4. Costs for the improvement of the thermo-technical characteristics of the building envelope - CIS [author, 6] 
With respect to the relatively restricted technological possibilities and the choice of the suitable insulators across the building shell it is possible to determine the costs for the other constructions in the same way.

Above mentioned costs are determined on the basis of target prices in the building industry stated by the national database and not always reflect the real actual price. For the precise determination of the total costs it is also advisable to compile the bill of quantities on the basis of the thermo-technical requirements and project documentation of the building. This is possible to evaluate later in the course of the tender (procurement) or looking for the provider by market prices common in place and time.

The exception is represented by the costs for the replacement (assembly) of the filling of the openings. In this case it is preferable to determine the costs with the help of the price offered by the chosen provider without converting it to the unit of measure.

\section{TOTAL INVESTMENT COSTS}

The total investment costs comprise the sum of the total costs for the individual changed layers of the shell of the building on the basis of chosen technology multiplied by the number of the units of measure.

The potential investment decision is possible to evaluate then for the individual layers of the building envelope or in a comprehensive way for the whole building. In the case of partial decision the economic effect in the form of the costs spent on the individual layers of the building shell is obvious from the very beginning and it is possible to compare it to the potential energy saving. Comprehensive evaluation is possible to be done by the cost indicators of the lifespan cycle of the building (Building Life Cycle Costs, BLCC) [11] and create model with investment options [12].

According to the valid legislative regulation by the edict $n$. 78/2013 Sb. about the energy performance of buildings, when determining the partial characteristics of the construction of the building shell it is necessary to fulfil the requirement for the total energy performance of the building in the way that this will be lower that the energy performance of the reference building. It is ensured in the cases when the energy performance of the building is determined according to the specific energy consumption EPA $\left[\mathrm{kWh} / \mathrm{m}^{2} \mathrm{a}\right]$ and the average heat transfer coefficient $\mathrm{U}_{\mathrm{em}}\left[\mathrm{W} / \mathrm{m}^{2} \mathrm{~K}\right]$ and should be at maximum equal to upper limit of the classification category „C“" $[13]$.

In the cases when it is possible to give reasons for the suggested solution for the individual layers of the building shell not to be efficient, it is possible to break away from the set design corresponding to the Czech standard CSN 73 0540. In the same way the above mentioned requirement does not need to be fulfilled in the cases of the partial changes to the building shells.

In relation to the determination of the costs due to the pricing system of the target prices ÚRS Praha, a. s., these costs does not always need to correspond to the costs quantified by the offers of the potential company providers. In these cases the costs can be modified according to the really achieved offer in the way that the distortion of the evaluation of the life span of the buildings does not appear. 


\section{DISCUSSION}

The above mentioned procedure represents the first step for the consecutive modelling of the potential investment options while comply with the optimal level according to [1], whereas it represents just a reference quantification at the level of the pilot study of the investment decision or its rejection. In further steps it is possible to make the quantification more precise especially regarding the real condition and characteristics of the building and model the individual investment options working with different technological processes, with various insulating materials etc. In relationship to the quantification of the individual costs and total investment costs it is subsequently possible to create tasks modelling the improvement of the thermo-technical characteristics of the buildings.

These conclusions work only with a variant of the minimal improvement of thermo- technical properties of the building envelope. The paper's contribution is not listed any cost-optimal variants. Finding these variants may be the next step to optimize the energy balance of buildings.

\section{CONCLUSION}

The measurements improving the thermo-technical characteristics of the building envelope need to be evaluated from the technical, thermo-technical and economic point of view. The fundamental aspect for the evaluation of the economic aspect is the quantification of partial and total costs according to the individual layers of the building shell and for the building as a whole. The above mentioned procedure enables to simplify the discussed issue so much that the accepted solutions come out of the comprehensive methods containing the quantification of the partial costs for the each individual construction of the building shell with the use of one of the used technological processes.

With the help of the above mentioned procedure it is possible to quantify the framework investment costs of the chosen option and on the basis of another input data determine the whole economic balance comprising the quantification of the costs for the life span of the buildings for the course of the life span investment. The aim of accepted solutions should be in the ideal case the balance between technical and economic aspects.

\section{REFERENCES}

[1] Directive of the European Parliament and of the Council 2010/31/ES Energy Performance of Buildings Directive (EPBD II) (revision).

[2] GIESELER, U. D. J., HEIDT, F. D., BIER, W., Evaluation of the cost efficiency of an energy efficient building, Renewable energy 29 (2004) page 369-376.

[3] HANÁK, T., RADUJKOVIĆ, M., VUKOMANOVIĆ, M., Economic evaluation of energy- saving measures on panel buildings in the Czech Republic.Tehničky vjestnikt - Technical gazette, 2013, roč. 20, č. 3, s. 497-504. ISSN: $1330-3651$.

[4] TYWONIAK, J., Nízkoenergetické domy, Principy a př́klady. Praha: GRADA, 2005 (dotisk 2007). 200 s. ISBN 80-247-1101-X

[5] SADINENI S. B., MADALA, S., BOEHM R, F., Passive building energy savings: A review of building envelope components, Renewable and Sustainable Energy Reviews, 2011, Vol.15(8), pp.3617-3631

[6] ČSN 73 0540-1,2,3,4: změna 2011 Tepelná ochrana budov. Part 1, 2, 3, 4. Praha: Český normalizační institut, 2005.

[7] Š́́LA, J., KEIM, L., SVOBODA, Z., TYWONIAK, J., Tepelná ochrana budov, komentár k ČSN 73 0540. Praha: ČKAIT 2008. 292 S. ISBN 978-80-87093-30-6

[8] VÝSKALA, M., KORYTÁROVÁ, J., Náklady na zlepšení tepelně technických vlastností budov. Recenzovaný časopis Stavebni obzor číslo 9/2010 s. 279 - 282, Praha: FS ČVUT, FS VŠB TU Ostrava, FS VUT v Brně, ČKAIT 2009, ISSN 1210-4027. 
[9] KOVACEVIC, I., SUMMER, M., ACHAMMER, C., Life-cycle Oriented Renovation Strategies for Social Housing Stock, Organization, technology and management in construction $\cdot$ a ninternational journal $\cdot 5(2) 201$, ISSN 1847-6228 (Online)

[10] Cenová databáze směrných cen cenové soustavy společnosti ÚRS Praha a. s., cenová hladina 2/2013 (stanovené náklady vychází z výstupů autorizovaného sw KROS PLUS).

[11] KORYTÁROVÁ, J., Celoživotní náklady budov. Recenzovaný časopis Stavební obzor čislo 7/2010 s. 219-221. Praha:

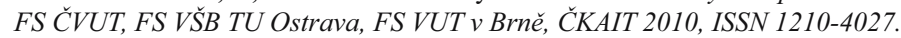

[12] VÝSKALA, M., Creating Models for Projects Improving the Thermal-Technical Properties of Buildings - Theoretical Basis. International Scietific Conference People, Buildings and Environment 2012. Brno: Vysoké učení technické v Brně, Fakulta stavební, ISBN 978-80-214-4616-8

[13] Vyhláška č. 78/2013 Sb., o energetické náročnosti budov zákona č. 406/2000 Sb. O hospodaření energií v platném znění. 